\title{
Secondary Metabolite and Antioxidant Activity of Endophytic Fungi Isolated from Syzygium aqueum Leaves Stalk
}

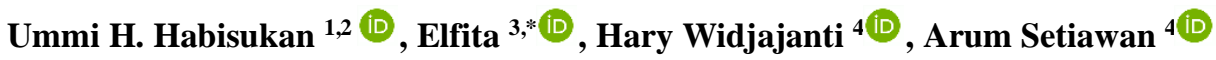

1 Graduate School of Sciences, Faculty of Mathematics and Natural Sciences, University of Sriwijaya,. Jl. Padang Selasa No. 524, Palembang 30139, South Sumatra, Indonesia; ummihirashabisukan@radenfatah.ac.id (U.H.H.);

2 Universitas Islam Negeri Raden Fatah Palembang, South Sumatra, Indonesia; ummihirashabisukan@radenfatah.ac.id (U.H.H.);

3 Department of Chemistry, Faculty of Mathematics and Natural Sciences, University of Sriwijaya, Jl. Palembang Prabumulih, Indralaya, South Sumatra, 30662 Indonesia; elfita.elfita.69@gmail.com (E.);

4 Department of Biology, Faculty of Mathematics and Natural Sciences, University of Sriwijaya, Jl. Palembang Prabumulih, Indralaya, South Sumatra, 30662 Indonesia; hary_widjajanti@unsri.ac.id (H.W.); arum.setiawan@unsri.ac.id (A.S.);

* Correspondence: elfita.elfita.69@gmail.com (E.);

Scopus Author ID 55532411800

Received: 23.10.2021; Revised: 19.11.2021; Accepted: 21.11.2021; Published: 25.11.2021

Abstract: Medicinal plants are a promising host for endophytic fungi to produce secondary metabolites relevant for food and health. In this study, we evaluate antioxidant activity to determine the species of endophytic fungi isolated from Syzygium aqueum. Endophytic fungi were isolated from leaf stalks through surface sterilization. The fungi's isolate was identified with morphology and molecular analysis (ITS-rDNA). The pure fungi strain was cultivated on PDB media for 4 weeks, and metabolites were extracted using ethyl acetate. The crude extract of endophytic fungi was examined for its antioxidant activity using 2,2-diphenyl-1-picrylhydrazyl (DPPH). The pure compound was isolated using the chromatography method, and its structure was determined using spectroscopy analysis involving NMR 1D and 2D. In total, four obtained endophytic fungi were isolated from leaf stalks. The fungi with good antioxidant activity $\left(\mathrm{IC}_{50} 59.2 \mu \mathrm{g} / \mathrm{mL}\right.$ ) were identified as Beltrania rhombica. The characteristics of the pure compound are white-yellowish powder with $\mathrm{IC}_{50} 44.2 \mu \mathrm{g} / \mathrm{mL}$. Based on spectroscopy analysis, the pure compound was identified as 3-(hydroxyl(3,4,5-trihydroxylphenyl)methyl)-3,4-dihydro-2H-pyran4,5,6-triol.

Keywords: secondary metabolite; endophytic fungi; Beltrania rhombica; antioxidant; Syzygium aqueum.

(C) 2021 by the authors. This article is an open-access article distributed under the terms and conditions of the Creative Commons Attribution (CC BY) license (https://creativecommons.org/licenses/by/4.0/).

\section{Introduction}

Antioxidants play an important role in hindering or preventing degenerative diseases caused by free radicals [1,2]. At the normal limit, the body has natural defenses to help it overcome the rise of free radicals [3,4]. Superoxide compounds can be pressed by antioxidants [5]. Antioxidants have become an interesting topic nowadays because of their ability to protect the human body from various diseases caused by free radical reactions and reduce oxidative stress [6]. Antioxidants are compounds that are widely used as industrial resources in the food and health fields. The use of synthetic antioxidants to protect against free radical damage has been reported to cause harmful effects $[7,8]$. Therefore, it is necessary to find a safer source of 
antioxidants from natural ingredients, such as jambu air (Syzygium aqueum), which has been reported to contain active antioxidant compounds, especially in their leaves [9].

In various parts of the world, including Indonesia, Syzygium aqueum has been used as medicine for its antioxidant activity [10,11]. The most abundant chemical compounds in Syzygium aqueum are flavonoids and phenols, which are found in almost all parts, such as leaves, flowers, fruit, seeds, roots, and bark. They have been reported to have antioxidant, antibacterial, antiviral, anti-inflammatory, anti-allergic, and antidiabetic activities and play a role in cancer prevention $[12,13]$. Currently, the search for natural bioactive is not only from plants but also from their endophytic fungi.

Endophytic fungi are microscopic living organisms that live in plant tissues (leaves, fruit, seeds, stems, and roots) at certain periods and form colonies without harming their hosts, even maintaining mutually beneficial relationships [14,7]. Endophytic fungi have been identified as a source of secondary metabolites, such as antioxidants, antibiotics, antivirals, antiprotozoal, antidiabetic, and anticancer agents. These compounds include alkaloids, terpenoids, steroids, isocoumarin derivatives, lactones, quinones, flavonoids, phenols, indole derivatives, lignins, tannins, anthraquinones, xanthones, phenylpropanoids, phenolic acids, and peptide peptides [15-17]. Natural products derived from endophytic fungi are considered as one of the most relevant sources of discovery and molecular diversity for new drugs. This is due to the large diversity of endophytic fungi species that can produce secondary metabolites with biological activity, plus the ease of cultivating endophytic fungi in large quantities and in a short time. [18-20]. Therefore, research on endophytic fungi that produce antioxidant compounds needs to be carried out on the host plant $S$. aqueum.

\section{Materials and Methods}

\subsection{Plant material.}

The plant material is Syzygium aqueum leaf stalk taken in the Sriwijaya University area, Indralaya, Ogan Ilir, South Sumatera, and identified at the Biosystematics Laboratory, Biology, FMIPA, Sriwijaya University, with certificate number: 329//UN9.1.7/4/EP/2020.

\subsection{Isolation and identification of endophytic fungi.}

The leaf stalks of $S$. aqueum were washed with running tap water and then dried. Fragments of it were surface-sterilized by immersing each sample in $70 \%$ alcohol for $1 \mathrm{~min}$, then in $3 \%$ sodium hypochlorite $(\mathrm{NaOCl})$ for $1 \mathrm{~min}$. After rinsing with sterile distilled water for $1 \mathrm{~min}$, the outer tissue was removed with a sterile scalpel. Small pieces of leave stalks were placed in a Petri dish containing PDA media supplemented with chloramphenicol $(0.2 \mathrm{~g} / \mathrm{L})$ then incubated for $7 \mathrm{~d}$ at $30 \pm 2^{\circ} \mathrm{C}$. All experiments were carried out in triplicate. Fungal growth from the leaf stalk segments was monitored every day. The individual hyphae tips were transferred to fresh PDA and incubated at $30^{\circ} \mathrm{C}$ for $7 \mathrm{~d}$. Pure cultures were numbered and maintained in a PDA slope and stored at $4^{\circ} \mathrm{C}$.

Identification of endophytic fungi through molecular analysis followed the procedure described [21], which was based on partial genetic analysis at the Internal Transcribed Spacer (ITS) ribosomal DNA of fungi. The phylogenetic tree construction was carried out using several applications: Clustal W, SEQBOOT, DNA dist, Neighbor, CONSENSE, and FigTree. 


\subsection{Cultivation and extraction.}

Endophytic fungal cultures were prepared on PDB media by placing $6 \mathrm{~cm}$ diameter agar blocks of pure culture into five $1 \mathrm{~L}$ Erlenmeyer flasks containing $300 \mathrm{~mL}$ of medium each. The flasks were incubated under static conditions at room temperature for 4 weeks. The culture was filtered through filter paper to separate the mycelium. The liquid broth was collected and extracted with ethyl acetate $(1: 1)$ in a separating funnel with vigorous shaking for 1 hour, then filtered. Extraction was carried out with two repetitions. The ethyl acetate extract was evaporated with a rotary evaporator to produce a concentrated extract $[3,22,23]$.

\subsection{Antioxidant activity assay.}

The antioxidant activity assay used the DPPH method [24]. A $0.05 \mathrm{mM}$ solution of DPPH in methanol was prepared, and $3.8 \mathrm{~mL}$ of this solution was mixed with $0.2 \mathrm{ml}$ of the test sample in methanol at a series concentration. 200, 100, 50, 25, 12.5, 6.75, and $0 \mu \mathrm{g} / \mathrm{mL}$ were prepared. The reaction mixture was thoroughly vortexed and left in the dark for $30 \mathrm{~min}$. The absorbance of the mixture was measured spectrophotometrically (Shimadzu, Uv-1900) at a wavelength of $517 \mathrm{~nm}$. Gallic acid is used as a standard antioxidant. The percentage of DPPH radical scavenging activity was calculated using the formula:

$\%$ Inhibition $=$ Control Absorbance-Sample Absorbance $\times 100 \%$

Control Absorbance

\subsection{Isolation and identification of secondary metabolites.}

The active extract (selected by $\mathrm{IC}_{50}$ highest value) was analyzed by thin-layer chromatography (TLC) of silica gel G-60 F 254 using solvents with various eluents to see the staining pattern. Column chromatography extract used a stationary phase such as silica gel. Samples that have been prepared by pre-absorption are fed into the chromatographic column evenly and eluted with a gradient system. The eluate was collected in vials every $10 \mathrm{ml}$, and each had a chromatographed thin layer to be grouped into column fractions based on the staining pattern. The visible stains were UV lamp at $254 \mathrm{~nm}$ and cerium sulfate spray reagent. Fractions containing potential compounds in column chromatography were used to obtain pure compounds. Identification of the chemical structure was carried out by spectroscopic analysis, which included ${ }^{1} \mathrm{H}-\mathrm{NMR},{ }^{13} \mathrm{C}-\mathrm{NMR}$, DEPT 135, HMQC, HMBC, and COSY (Agilent DD2 $500 \mathrm{MHz}\left({ }^{1} \mathrm{H}\right)$ dan $\left.125 \mathrm{MHZ}\left({ }^{13} \mathrm{C}\right)\right)$.

\section{Results and Discussion}

The isolation of endophytic fungi from leaf stalks of $S$. aqueum obtained four isolates, three of which were the same as endophytic fungi obtained from leaves: Cochliobolus sp., Penicillium sp., and Fusarium sp. The difference was one fungus labeled B52. The results of the molecular identification of Sequence Assembly 572 bp are

CGTAGGTGAACCTGCGGAGGGATCATTACAGAGTTTTCTAAACTCCCAAACCCAT GTGAACTTACCATTGTTGCCTCGGCGGAGCCTACCCTGTAGCTACCCTATAAGGT GGTACCCTGTAGCGCCCCGCCGGTGGATTTTCAAACTCTTGTTATTTATAGTAATC TGAGAGTCTTATTTTAAATAAGTCAAAACTTTCAACAACGGATCTCTTGGCTCTG GCATCGATGAAGAACGCAGCGAAATGCGATAAGTAATGTGAATTGCAGAATTCA 
GTGAATCATCGAATCTTTGAACGCACATTGCGCCCATTAGTATTCTAGTGGGCAT GCCTGTTCGAGGTCATTTCAACCCTTAAGCCTAGCTTAGTGTTGGGAGTCTACGA GTGGGCCACGTTACCCTGTAGCGTGGTTACCCTGTAGTTCCTGAAAATCAACGGC GGATTTACAGTATCCTCTGAGCGTAGTAATTCTTTATCTCGCTTCTGTTTAGGTGC TGTGACTTCGGCCGCTAAACCCCACAATTTTTTTGTGGTTGACCTCGGATCAGGT AGGAATACCCGCTGAACTTAAGCAT

The strain B52 has accession number OK376219. The results of the B52 endophytic fungal phylogeny tree construction are shown in Figure 1. The B52 phylogenetic tree showed that the isolate sequence was in the same branch as Beltrania rhombica. Phylogenetic analysis indicated that isolate B52 was Beltrania rhombica. It was carried out using Clustal W, Seqboot, DNA dist, Neighbor, Consense, and FigTree.

The endophytic fungus isolate culture B52 in 5 Erlenmeyer flasks containing $300 \mathrm{~mL}$ PDB medium was incubated for 4 weeks at room temperature and dark conditions. Extraction of endophytic fungi using ethyl acetate solvent, after evaporation, produces a concentrated extract of ethyl acetate $6.2 \mathrm{~g}$. The antioxidant activity test gave $\mathrm{IC}_{50}$ a value of $59.2 \mu \mathrm{g} / \mathrm{mL}$, while the $\mathrm{IC}_{50}$ values for the other three endophytic fungi were $98.26 \mathrm{~g} / \mathrm{mL}$ (Cochliobolus $\mathrm{sp}$.), $92.3 \mathrm{~g} / \mathrm{mL}$ (Penicillium sp.), and $64.33 \mathrm{~g} / \mathrm{mL}$ (Fusarium sp.).

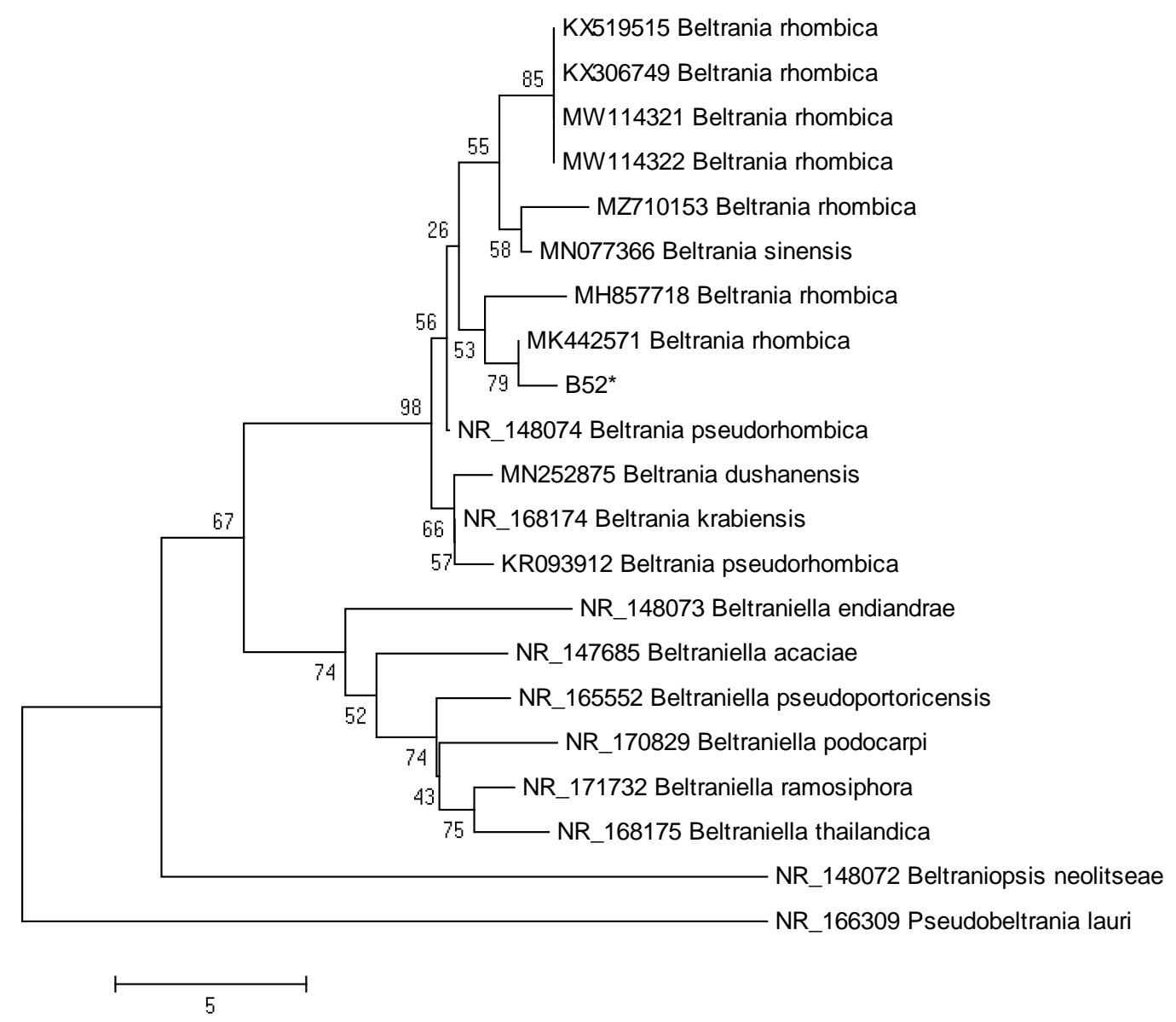

Figure 1. Phylogenetic tree of the endophytic fungal B52 was carryout using applications: Clustal W, Seqboot, DNA dist, Neighbor, Consense, and Fig Tree.

The results of the TLC analysis of the concentrated ethyl acetate extract showed that there was a major purple stain at Rf 0.55 , with n-hexane:ethyl acetate as the eluent $(2: 8)$. Therefore, the eluent to be used in column chromatography can use a stepwise system. Ethyl acetate extract $2 \mathrm{~g}$ was pre-absorbed with silica gel as stationary phase 70-230 nesh in a ratio 
(1:1). Separation of pure compounds was carried out by column chromatography, which was eluted with a mixture of $n$-hexane and ethyl acetate (10:0-0:10), and a mixture of ethyl acetate and methanol (9:1). The eluate was collected every $10 \mathrm{~mL}$ in the vial until 65 vials were obtained. Based on TLC analysis, four subfractions (F1-F4) were obtained. Subfraction F3 showed major stains and continued purification by column chromatography until pure compound (compound 1) was obtained in the form of a yellowish-white solid (44 mg). The antioxidant activity test gave an $\mathrm{IC}_{50}$ value of $44.2 \mu \mathrm{g} / \mathrm{mL}$.

\subsection{Determination of chemical structure.}

The ${ }^{1} \mathrm{H}-\mathrm{NMR}$ spectrum of compound 1 (Fig. 2) shows the presence of 11 proton signals, including two doublet signals, in the aromatic chemical shift region, namely, at $\delta_{\mathrm{H}} 7.70$ and $8.19 \mathrm{ppm}$, each of which has a double integration and coupling constant of $\mathrm{J}=8.5 \mathrm{~Hz}$. This indicates that compound 1 has a para-substituted aromatic structure, with two pairs of equivalent protons. Five other signals appear in the sp3 proton region, namely, two oxygenated methine signals, namely, at $\delta_{\mathrm{H}} 5.33(1 \mathrm{H}, \mathrm{m}) ; 6.37(1 \mathrm{H}, \mathrm{s})$; and two oxygenated methylene proton signals that appear at different chemical shifts, namely, at $\delta_{\mathrm{H}} 3.70(1 \mathrm{H}, \mathrm{m})$ and $3.79 \mathrm{ppm}$ $(1 \mathrm{H}, \mathrm{m})$, while the other sp3 signal is proton methine at $\delta_{\mathrm{H}} 4.16 \mathrm{ppm}(1 \mathrm{H}, \mathrm{m})$. In addition, there are four proton signals that, after being confirmed with the HMQC spectrum (Fig. 4), turn out not to be bound to the carbon atom. This indicates that these signals are proton signals bound to heteroatoms, such as hydroxyl protons.

The ${ }^{13} \mathrm{C}-\mathrm{NMR}$ spectrum of compound 1 (Fig. 3) showed 10 signals: four sp3 carbon signals and six other signals that appeared in the sp2 carbon region. After confirmation with DEPT 135 spectrum, it was found that the four sp3 carbon signals were two oxygenated methine carbon signals $\left(\delta_{\mathrm{C}} 71.2\right.$ and $\left.67.5 \mathrm{ppm}\right)$, one oxygenated methylene carbon signal $\left(\delta_{\mathrm{C}}\right.$ $62.2 \mathrm{ppm})$, and one tertiary carbon signal $\left(\delta_{\mathrm{C}} 58.0 \mathrm{ppm}\right)$. Two high-intensity signals in the sp2 carbon region indicate that compound 1 has two pairs of equivalent aromatic carbons $\left(\delta_{\mathrm{C}} 123.9\right.$ and $128.2 \mathrm{ppm}$ ). Four other sp2 carbon signals were at $\delta_{\mathrm{C}} 148.1,151.5,164.4$, and $164.5 \mathrm{ppm}$, respectively, after being confirmed with DEPT 135 spectrum. It is known that the four carbons are quaternary.

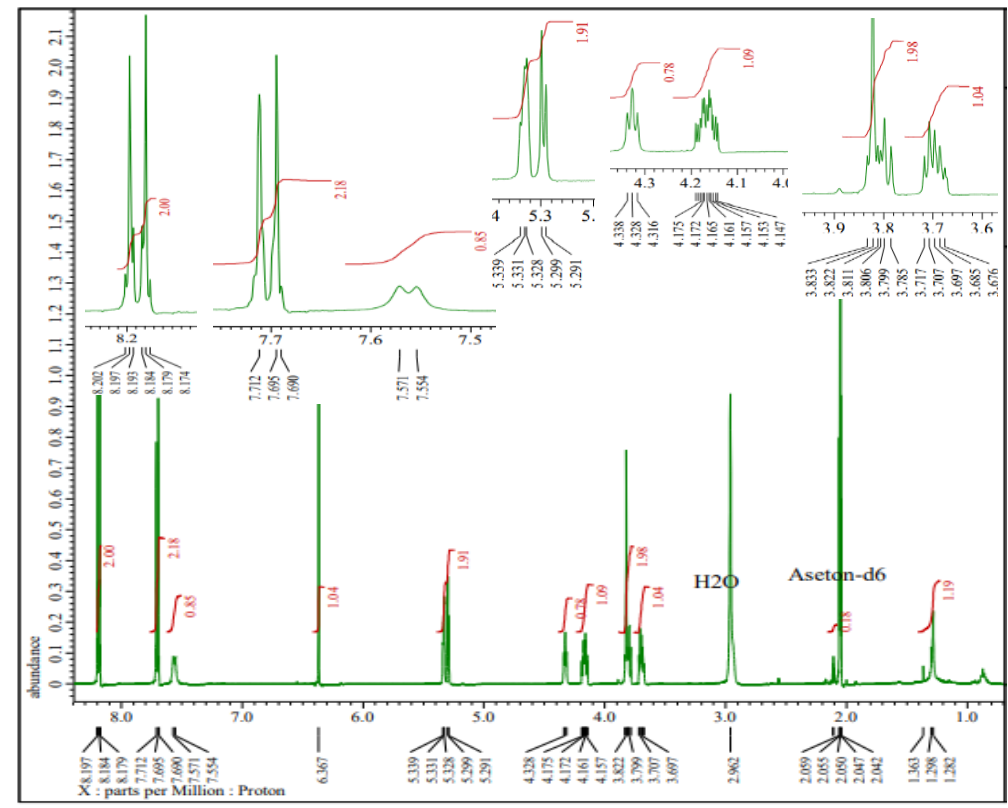

Figure 2. The ${ }^{1} \mathrm{H}-\mathrm{NMR}$ spectra of compound 1. 

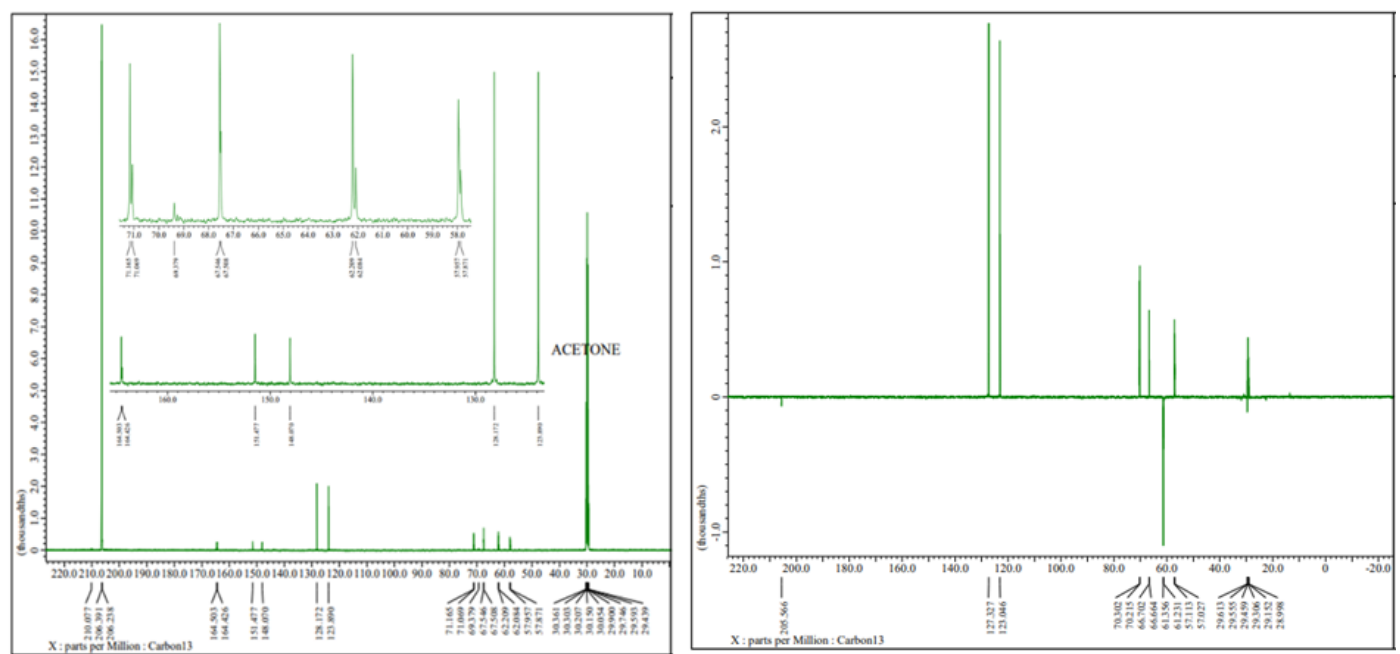

Figure 3. The ${ }^{13} \mathrm{C}-\mathrm{NMR}$ (A) DEPT 135 (B) spectra of compound 1.

The analysis of the proton and carbon NMR spectra is confirmed by the data on the HMQC spectrum (Fig. 4) the ${ }^{1} \mathrm{H}^{-13} \mathrm{C}$ correlation through one bond. The HMQC spectrum showed six correlations consisting of two ${ }^{1} \mathrm{H}_{-}{ }^{13} \mathrm{C}$ correlations on the aromatic ring, three correlations on oxygenated ${ }^{1} \mathrm{H}-{ }^{13} \mathrm{C}$, and one ${ }^{1} \mathrm{H}_{-}{ }^{13} \mathrm{C}$ correlation for methine. Thus, the 11 signals that appear on proton NMR consist of seven signals bound to the carbon atom (two nonequivalent methylene proton signals) and four protons bound to the heteroatom.
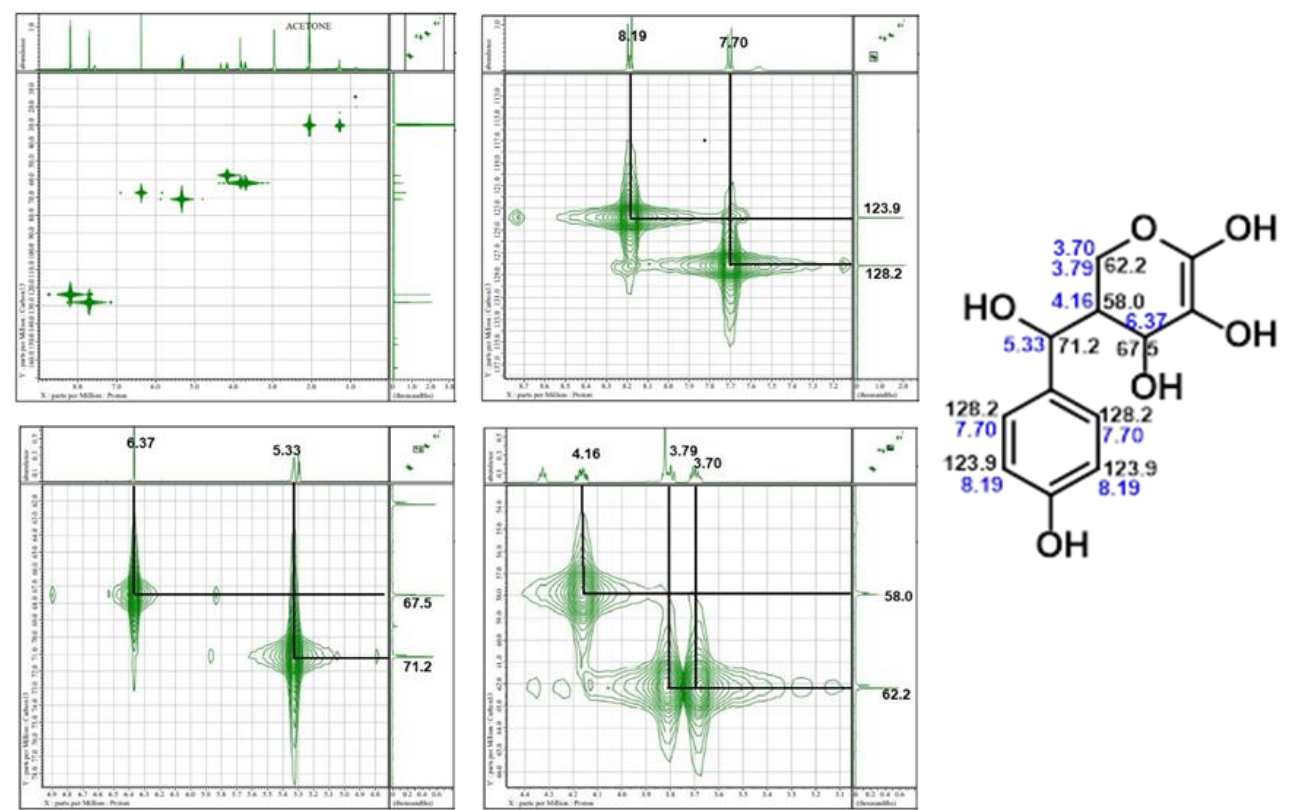

Figure 4. The HMQC spectra of compound 1.

The HMBC spectrum (Fig. 5) showed a ${ }^{1} \mathrm{H}-{ }^{13} \mathrm{C}$ correlation through two or three bonds. The aromatic proton signal at $\mathrm{H} 8.19 \mathrm{ppm}$ showed three correlations: a correlation each with ortho aromatic carbon $\left(\delta_{\mathrm{C}} 128.2 \mathrm{ppm}\right)$, its equivalent aromatic carbon $\left(\delta_{\mathrm{C}} 123.9 \mathrm{ppm}\right)$, and quaternary aromatic carbon $\left(\delta_{\mathrm{C}} 148.1 \mathrm{ppm}\right)$. Another aromatic proton at $\mathrm{H} 7.70 \mathrm{ppm}$ has four correlations: a correlation each with ortho aromatic carbon $\left(\delta_{\mathrm{C}} 123.9 \mathrm{ppm}\right)$, its equivalent aromatic carbon $\left(\delta_{\mathrm{C}} 128.2 \mathrm{ppm}\right)$, quaternary aromatic carbon $\left(\delta_{\mathrm{C}} 148.1 \mathrm{ppm}\right)$, and oxygenated side-chain carbon $\left(\delta_{\mathrm{C}}\right) 71.2 \mathrm{ppm}$.

Furthermore, oxygenated methine protons at $\delta_{\mathrm{H}} 5.33 \mathrm{ppm}$ have three ${ }^{1} \mathrm{H}-{ }^{13} \mathrm{C}$ correlations via three bonds: aromatic carbon $\left(\delta_{\mathrm{C}} 128.2 \mathrm{ppm}\right)$ and oxygenated carbon $\left(\delta_{\mathrm{C}} 58.0\right.$ 
and $62.2 \mathrm{ppm}$ ). The correlation indicates that the oxygenated methine group at $\delta_{\mathrm{H}} 5.33 \mathrm{ppm}$ is directly attached to the aromatic ring and is para-substituted with a hydroxyl group. The oxygenated methylene proton $\left(\delta_{\mathrm{H}} \mathrm{A}=3.70 ; \mathrm{B}=3.79 \mathrm{ppm}\right)$ had two ${ }^{1} \mathrm{H}_{-}{ }^{13} \mathrm{C}$ correlations with two bonds with oxygenated methine carbon at $\delta_{\mathrm{C}} 58.0 \mathrm{ppm}$ and a triple correlation with oxygenated methine carbon at $\delta_{\mathrm{C}} 71.2 \mathrm{ppm}$. The 1D and 2D NMR spectral data for compound 1 are shown in Table 1.
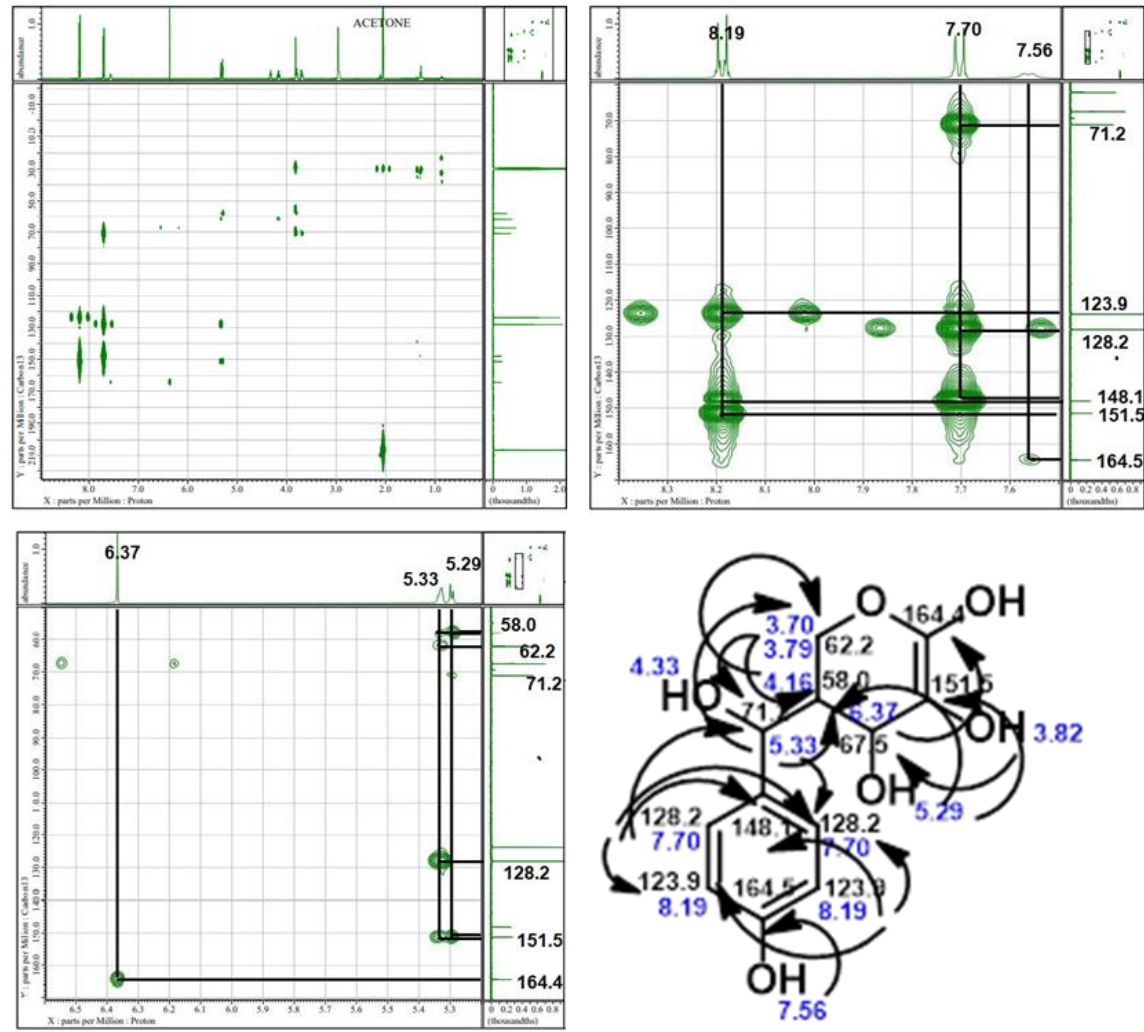

Figure 5. The HMBC spectra of compound 1.

Table 1. The NMR data of Compound 1.

\begin{tabular}{|c|c|c|c|c|c|}
\hline No. $\mathrm{C}$ & $\delta_{\mathrm{c}} \mathrm{ppm}$ & DEPT 135 & $\delta_{H}$ ppm $(\Sigma H$. multiplicity. $J(\mathbf{H z}))$ & НMBC & COSY \\
\hline 2 & 62.2 & $\mathrm{CH}_{2}$ & $\begin{array}{l}\mathrm{A}=3.70(1 \mathrm{H}, \mathrm{m}) \\
\mathrm{B}=3.79(1 \mathrm{H}, \mathrm{m})\end{array}$ & $\begin{array}{l}58.0 ; 71.2 \\
58.0 ; 71.2\end{array}$ & $\begin{array}{l}4.16 \\
4.16 \\
\end{array}$ \\
\hline 3 & 58.0 & $\mathrm{CH}$ & $4.16(1 \mathrm{H}, \mathrm{m})$ & 62.2 & $5.33 ; 3.70 ; 3.79$ \\
\hline 4 & 67.5 & $\mathrm{CH}$ & $6.37(1 \mathrm{H}, \mathrm{s})$ & 164.4 & - \\
\hline 5 & 151.5 & $\mathrm{C}$ & - & - & - \\
\hline 6 & 164.4 & $\mathrm{C}$ & - & - & - \\
\hline 1 , & 148.1 & $\mathrm{C}$ & - & - & - \\
\hline 2 ' & 128.2 & $\mathrm{CH}$ & $7.70(1 \mathrm{H}, \mathrm{d}, \mathrm{J}=8.5)$ & $71.2 ; 128.2 ; 148.1 ; 123.9$ & 8.19 \\
\hline 3 & 123.9 & $\mathrm{CH}$ & $8.19(1 \mathrm{H}, \mathrm{d}, \mathrm{J}=8.5)$ & $123.9 ; 148.1 ; 128.2$ & 7.70 \\
\hline $4^{\prime}$ & 164.5 & $\mathrm{C}$ & - & - & - \\
\hline 5 , & 123.9 & $\mathrm{CH}$ & $8.19(1 \mathrm{H}, \mathrm{d}, \mathrm{J}=8.5)$ & $123.9 ; 148.1 ; 128.2$ & 7.70 \\
\hline 6 ' & 128.2 & $\mathrm{CH}$ & $7.70(1 \mathrm{H}, \mathrm{d}, \mathrm{J}=8.5)$ & $71.2 ; 128.2 ; 148.1 ; 123.9$ & 8.19 \\
\hline 7 & 71.2 & $\mathrm{CH}$ & $5.33(1 \mathrm{H}, \mathrm{m})$ & $128.2 ; 58.0 ; 62.2$ & $4.16 ; 7.70$ \\
\hline $\mathrm{OH}$ & - & & 3.82 & 67.5 & - \\
\hline $\mathrm{OH}$ & - & & 4.33 & - & - \\
\hline $\mathrm{OH}$ & - & & 5.29 & $58.0 ; 151.5$ & - \\
\hline $\mathrm{OH}$ & - & & 7.56 & 164.5 & - \\
\hline
\end{tabular}

The COSY spectrum in Figure 6 appears to show that the aromatic proton at $\delta_{\mathrm{H}} 7.70$ ppm has a ${ }^{1} \mathrm{H}-{ }^{1} \mathrm{H}$ correlation through three bonds with an aromatic proton $\delta_{\mathrm{H}} 8.19 \mathrm{ppm}$ and a ${ }^{1} \mathrm{H}-{ }^{1} \mathrm{H}$ correlation through more than three bonds with the oxygenated $\mathrm{sp} 3$ methine proton at $\delta_{\mathrm{H}} 5.33 \mathrm{ppm}$ bound to an aromatic ring. The methine proton at $\delta_{\mathrm{H}} 4.16 \mathrm{ppm}$, part of the side chain, has a ${ }^{1} \mathrm{H}-{ }^{1} \mathrm{H}$ correlation through three bonds with the oxygenated $\mathrm{sp} 3$ methine proton $\left(\delta_{\mathrm{H}}\right.$ 
$5.33 \mathrm{ppm})$ and oxygenated methylene proton $\left(\delta_{\mathrm{H}} 3.70\right.$ and $\left.3.79 \mathrm{ppm}\right)$. This ${ }^{1} \mathrm{H}-{ }^{1} \mathrm{H}$ correlation of the COSY spectrum indicates that the two aromatic equivalent protons are in the ortho position. This strengthens the proposed structure: compound 1 is a benzene ring directly bonded to the oxygenated methine carbon at the para position with a hydroxyl group.
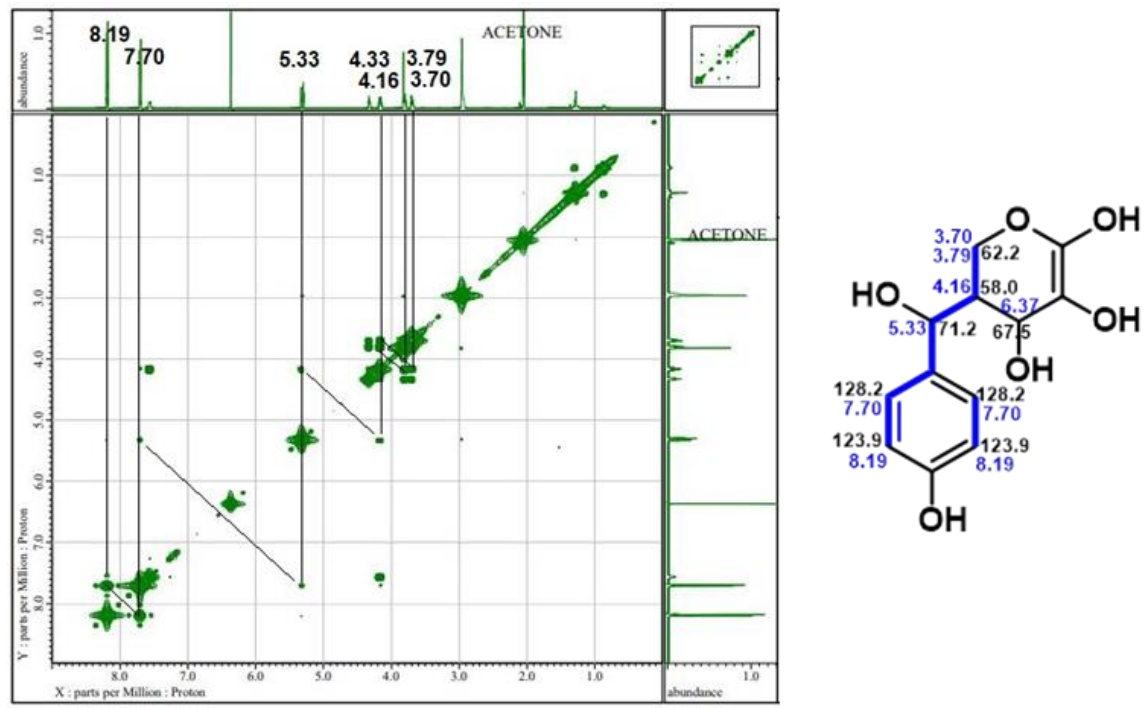

Figure 6. The COSY spectra of compound 1.

Based on the spectrum analysis of ${ }^{1} \mathrm{H}-\mathrm{NMR},{ }^{13} \mathrm{C}-\mathrm{NMR}$, DEPT 135, HMQC, HMBC, and COSY, it can be explained that compound 1 has a para-substituted frame on the benzene ring. It was identified from the presence of two aromatic proton signals with the integration of two protons. The multiplicity of the two signals is doublet with the same coupling constant ( $\mathrm{J}$ $=8.5 \mathrm{~Hz}$ ). This indicates that the two protons bound to the aromatics are in the ortho position, and the two substituents are bound to para (Fig. 2). One of the substituents is a hydroxyl group, which is characterized by a chemical shift value of oxyaryl carbon at $\delta_{\mathrm{C}} 164.5 \mathrm{ppm}$, while the second substituent is carbon methine $\mathrm{sp} 3\left(\delta_{\mathrm{C}} 71.2 \mathrm{ppm}\right)$, which has a hydroxyl group and a pyran-4,5,6-triol group (Fig. 3). Furthermore, the three hydroxyl groups attached to the pyran ring can be validated from the $\mathrm{HMBC}$ spectrum in the presence of a ${ }^{1} \mathrm{H}_{-}{ }^{13} \mathrm{C}$ correlation through two or three bonds. In addition, the binding of the pyran group to $\mathrm{C}$ methine (C-7') can be identified from the COSY spectrum (Fig. 6) through the ${ }^{1} \mathrm{H}-{ }^{1} \mathrm{H}$ three-bond correlation.

The proton at $\delta_{\mathrm{H}} 6.37 \mathrm{ppm}$ appears singlet, possibly due to the transposition with the proton at $\delta_{\mathrm{H}} 4.16 \mathrm{ppm}$, as shown in Figure 7, so the distant position does not cause cleavage. Thus, the proposed chemical structure of compound 1 is 3-(hydroxy(4hydroxyphenyl)methyl)-3,4-dihydro-2H-pyran-4,5,6-triol, as shown in Figure 7.

Compound 1 has good antioxidant activity due to the easy abstraction of hydroxyl protons by DPPH free radicals and generates new free radicals that can be stabilized by radical delocalization in the compound. Compounds with 1,2-dihydroxy units in the $\mathrm{C}=\mathrm{C}$ bond are more susceptible to proton abstraction by free radicals to form more stable free radicals. This stability is due to the free radicals produced, forming intramolecular hydrogen bonds with the adjacent hydroxyl group and a diketone. Likewise, compounds with a hydroxyl group at the para position are prone to proton abstraction by free radicals to form new, more stable free radicals. This stability is due to the distribution and delocalization of electrons [25-27]. 


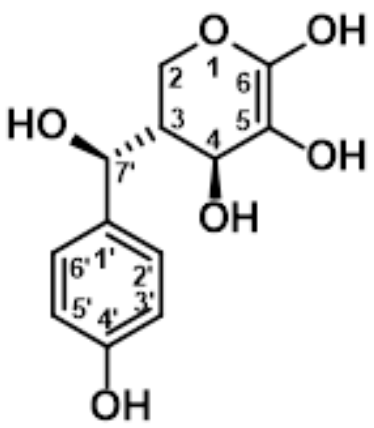

Figure 7. Compound 1 as 3-(hydroxy(4-hydroxyphenyl)methyl)-3,4-dihydro-2H-pyran-4,5,6-triol.

The antioxidant activity of compound 1 can be increased by carrying out a semisynthetic reaction similar to the position of the hydroxyl group on gallic acid (antioxidant standard). The $\mathrm{OH}$ group on the aromatic ring of compound 1 is ortho directive so that with the electrophilic substitution reaction, Nitration $\left(2 \mathrm{~mol} \mathrm{HNO}_{3} / \mathrm{H} 2 \mathrm{SO}_{4}\right)$, followed by a reduction of the nitro group $(\mathrm{Fe} / \mathrm{HCl})$, will produce two amine groups at $\mathrm{C} 3$ and $\mathrm{C}$. The next step is transforming the amine functional group into aryldiazonium chloride $\left(\mathrm{ArN}_{2}{ }^{+} \mathrm{Cl}^{-}\right)$and its final replacement by $-\mathrm{OH}$ through the reaction between the diazonium salt and hot aqueous acid [28]. Through this series of reactions, it is expected to produce 3-(hydroxyl $(3,4,5-$ trihydroxyphenyl)methyl)-3,4-dihydro-2H-pyran-4,5,6-triol compounds with antioxidant activity close to gallic acid, where gallic acid has a strong antioxidant with an $\mathrm{IC}_{50}$ value of $11.4 \mu \mathrm{g} / \mathrm{mL}$. The production of compound 1 can be carried out within 4 weeks of incubation, and the enrichment technique needs to be investigated further so that it can be produced as needed.

Endophytic fungi from the Beltraniaceae family can produce a variety of bioactive compounds [29]. Beltrania species is one of the rare endophytic fungi that are rarely found [30]. From the ethyl acetate extract of the culture broth of Beltrania rhombica, two new eudesmane sesquiterpenes, named rhombidiol and rhombitriol, were isolated. These secondary metabolites have antibacterial and antifungal activity [31]. Beltrania querna isolated from Amazonian medicinal plants contains active antiviral compounds [32]. Beltrania species showed their importance for the production of antitumor agents. Two new sesquiterpenes were isolated from the culture broth of Beltrania species [33], and sesquiterpenes are well known to have a potential application as an anticancer agent [34].

The results of the literature study [12,35] produced a report that the phenyl compounds from S. aqueum and other Syzygium spp. (Fig. 8) were not the same as compound 1. This indicates that compound 1 is typically produced by the endophytic fungus Beltrania rhombica of $S$. aqueum. There is no genetic evolution between fungal and host genes in producing compound 1.

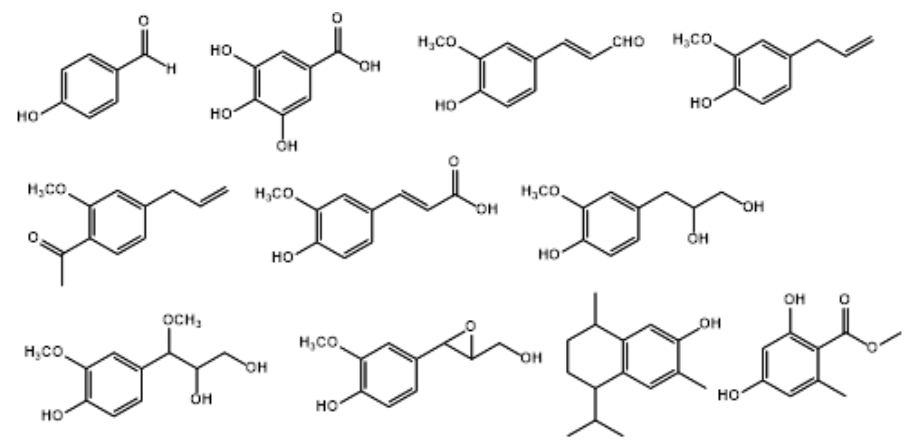

Figure 8. Phenyls of S. aqueum and other Syzygium spp. 
Some endophytic fungi produce certain phytochemical compounds that are also produced by their host plants. This is thought to be the result of genetic transfer from the host plant to endophytic fungi. Studies have shown that about $18 \%$ of plant-derived metabolites can also be derived from related fungi. That is the case with anticancer compounds, such as taxol and podophyllotoxin. Taxol is produced from the medicinal plant Taxus spp. and the endophytic fungus Taxomyces andreanae. Podophyllotoxin compounds are produced from the Sinopodophyllum hexadrum plant and its endophytic fungus Fusarium solani [36-38]. In recent years, endophytic fungi have become a source of secondary metabolite production. A total of 449 new secondary metabolites were produced from different tissues and plants with different chemical structures and biological activities. Among these new compounds, terpenoids constituted the largest proportion (26\%), followed by ketones (22\%), lactones (7\%), anthraquinones (5\%), steroids, penylpropanoids, alkaloids each $3 \%$ and other compounds (31\%) [39].

\section{Conclusions}

Endophytic fungi B52 were isolated from Syzygium aqueum leaves stalk identified as Beltrania rhombica produced compound 1 as 3-(hydroxy(4-hydroxyphenyl)methyl)-3,4dihydro-2H-pyran-4,5,6-triol, which is a phenolic compound that has antioxidant activity that can be developed as a source of new antioxidants. The compound produced by Beltrania rhombica is a promising potential source as a drug raw material in the future through several stages of simple semisynthetic reactions.

\section{Funding}

The research was funded by Daftar Isian Pelaksanaan Anggaran (DIPA) Universitas Sriwijaya,Indonesia, through Unggulan Profesi grants 2020, number 0009/UN9/SK.LP2M.PT/2020, September 28, 2020.

\section{Acknowledgments}

The authors wish to respect the facilities' support of the Organic Chemistry and Microbiology Laboratory, Faculty of Mathematics and Natural Sciences, University of Sriwijaya.

\section{Conflicts of Interest}

The authors declare no conflict of interest.

\section{References}

1. Septiana, E.; Bustanussalam; Yadi; Rachman, F; Hapsari, Y; Izzati, F.N.; Rahmawati, S.I.; Simanjuntak, P. Antioxidant activity of endophytic fungi from young and old leaves of cinnamon plants from Bogor, Indonesia. IOP Conf. Series: Earth and Environmental Science 2021, 762, 1-10, https://doi.org/10.1088/1755-1315/762/1/012038.

2. Stagos, D. Antioxidant Activity of Polyphenolic Plant Extracts. Antioxidants 2020, 9, 1-7, https://doi.org/10.3390/antiox9010019.

3. Elfita; Mardiyanto, M.; Fitrya, F.; Larasati; Julinar, J.; Widjajanti, H.; Muharni, M. Antibacterial activity of Cordyline fruticosa leaf extracts and its endophytic fungi extracts. Biodiversitas 2019, 20, 3804-3812, https://doi.org/10.13057/biodiv/d201245.

4. Mehdi, S.R.; Nanjangud, V.; Anil, K.; Paolo, Z.; Elena, M.V.; Luciana, D.; Elisa, P.; Jovana, R.; Patrick, V.; Tsouh, F.; Elena, A.; Ilaria, P.; Abhay, P.M.; Manisha, N.; Youssef, E.I.R.; Marc, E.I.B.; Letizia, P.; Marcello, I.; Natália, M.; Miquel, M.; Anca, O.D.; William, N.; Setzer; Daniela, C.; William, C.C.; Javad, 
S.-R. Lifestyle, oxidative stress, and antioxidants: back and forth in the pathophysiology of chronic diseases. Front Physiol 2021, 11, https://doi.org/10.3389/fphys.2020.00694.

5. Mucha, P.; Skoczy'nska, A.; Małecka, M.; Hikisz, P.; Budzisz, E. Overview of the antioxidant and antiinflammatory activities of selected plant compounds and their metal ions complexes. Molecules 2021, 26, 4886, https://doi.org/10.3390/molecules26164886.

6. Aragon, M.O.H.; Martinez, M.F.; Isiordia, E.M.A.; Contreras, D.L.; Juan, M.J.R.Z.; Gonzalez, R.M.L. Bacterial resistance and failure of clinical cure could be produced by oxidative stress in patients with diabetes or cardiovascular diseases during fluoroquinolone therapy. Medical Hypotheses 2017, 103, 32-34, https://doi.org/10.1016/j.mehy.2017.04.004.

7. Ibrahim, M.; Oyebanji, E.; Fowora, M.; Aiyeolemi, A.; Orabuchi, C.; Akinnawo, B.; Adekunle, A. Extracts of endophytic fungi from leaves of selected Nigerian ethnomedicinal plants exhibited antioxidant activity. BMC Complementary Medicine and Therapies 2021, 21, 1-13, https://doi.org/10.1186/s12906-021-03269-3.

8. Habisukan, U.H.; Elfita, W.H.; Setiawan, A.; Kurniawati, A.R. Diversity of endophytic fungi in Syzygium Aqueum. Biodiversitas 2021, 22, 1129-1137, https://doi.org/10.13057/biodiv/d220307.

9. Sobeh, M. Syzygium aqueum: a polyphenol- rich leaf extract exhibits antioxidant, hepatoprotective, painkilling and anti-inflammatory activities in animal models. Front Pharmacol 2018, 9, 1-14, https://doi.org/10.3389/fphar.2018.00566.

10. Habisukan, U.H.; Elfita, W.H.; Setiawan, A.; Kurniawati, A.R. Antioxidant and antimicrobial activity of endophytyc fungi isolated from Syzygium aqueum Leaves. Journal of Physics: Conference Series 2021, 1751, 1-8, https://doi.org/10.1088/1742-6596/1751/1/012059.

11. Sobeh, M.; Braun, M.S.; Krstin, S.; Youssef, F.S.; Ashour, M.L.; Wink, M. Chemical profiling of the essential oils of Syzygium aqueum, Syzygium samarangense, and Eugenia uniflora and their discrimination using chemometric analysis. Chem Biodivers 2016, 13, 1537-1550, https://doi.org/10.1002/cbdv.201600089.

12. Aung, E.E.; Kristanti, A.N.; Aminah, N.S.; Takaya, Y.; Ramadhan, R. Plant description, phytochemical constituents and bioactivities of Syzygium genus: A review. A Review De Gruyter Open Chemistry 2020, 18, 1256-1281, https://doi.org/10.1515/chem-2020-0175.

13. Tandi, J. Pengaruh ekstrak etanol daun jambu air (Syzygium aqueum(Burm f.)Alston) terhadap glukosa darah, ureum dan kreatinin tikus putih (Rattus norvegicus) J. Trop. Pharm. Chem 2017, 4, 43-51, https://doi.org/10.25026/jtpc.v4i2.137.

14. Khan, R.; Naqvi, S.T.; Ousain; Fatima, N.; Muhammad, S.A. Study of antidiabetic activities of endophytic fungi isolated from plants. Pure and Applied Biology 2019, 8, 1287-1295, http://dx.doi.org/10.19045/bspab.2019.80071.

15. Manganyi, M.C.; Ateba, C.N. Untapped potentials of endophytic fungi: A review of novel bioactive compounds with biological applications. Microorganisms $2020,8, \quad$ 1-25, https://doi.org/10.3390/microorganisms8121934.

16. Gakuubi, M.M.; Munusamy, M.; Liang, Z.X.; Ng, S.B. Fungal endophytes: a promising frontier for discovery of novel bioactive compounds. J. Fungi 2021, 7, https://doi.org/10.3390/jof7100786.

17. Cruz, J.S.; da Silva, C.A.; Hamerski, L. Natural products from endophytic fungi associated with rubiaceae species. Journal of Fungi 2020, 6, 1-26, https://doi.org/10.3390/jof6030128.

18. El-Hawary, S.S.; Moawad, A.S.; Bahr, H.S.; Abdelmohsen, U.R.; Mohammed, R. Natural product diversity from the endophytic fungi of the genus Aspergillus. RSC Advances 2020, 10, 22058-22079, https://doi.org/10.1039/D0RA04290K.

19. Co, I.E.; Cheesman, M. Plants of the genus Syzygium (Myrtaceae): A review on ethnobotany, medicinal properties and phytochemistry. In: Bioactive Compounds of Medicinal Plants: Properties and Potential for Human Health. Academic Press: Elsevier Inc 2018; pp. 35-84.

20. Rai, N.; Keshri, P.K.; Verma, A.; Kamble, S.C.; Mishra, P.;Barik, S.; Singha, S.K.; Gautam, V.G. Plant associated fungal endophytes as a source pf natural bioactive compounds. Mycology 2021, 12, 139-159, https://doi.org/10.1080/21501203.2020.1870579.

21. Yohandini, H.; Julinar; Muharni. Isolation and phylogeneticanalysis of thermophile community within Tanjung Sakti hot spring, South Sumatera, Indonesia. Hayati Journal of Biosciences 2015, 22, 143-148, https://doi.org/10.1016/j.hjb.2015.10.006.

22. Pansanit, A.; Pripdeevech, P. Antibacterial secondary metabolites from an endophytic fungus, Arthrinium sp. MFLUCC16-1053 isolated from Zingiber cassumunar. Mycology 2018, 9, 264-272, https://doi.org/10.1080/21501203.2018.1481154.

23. Marcellano, J.P.; Collanto, A.S.; Fuentes, R.G. Antibacterial activity of endophytic fungi isolated from the bark of Cinnamomum mercadoi. Pharmacognosy Journal 2017, 9, 405-409, https://doi.org/10.5530/pj.2017.3.69.

24. Muharni, M.; Elfita, E.; Yohandini, H.; Julinar, J.; Yasrina, Y.; Miranti, M. Chemical constituents from stem bark of Flacourtia rukam Zoll. \& Mor. and their antioxidant activities. Sains Malaysiana 2019, 48, 18991906, http://dx.doi.org/10.17576/jsm-2019-4809-10.

25. Sawai, Y.; Sakata, K. NMR Analytical approach to clarify the antioxidative molecular mechanism of catechins using 1,1-Diphenyl-2- picrylhydrazyl. Journal of Agricultural and Food Chemistry 1998, 46, 111114, https://doi.org/10.1021/jf970342x. 
26. Procházková, D.; Boušová, I.; Wilhelmová, N. Antioxidant and prooxidant properties of flavonoids. Fitoterapia 2011, 82, 513-523, https://doi.org/10.1016/j.fitote.2011.01.018.

27. Brunetti, C.; Martina, D.; Ferdinando, M.D.; Fini, A.; Pollastri, S.; Tattini, M. Flavonoids as antioxidants and developmental regulators: relative significance in plants and humans. International Journal of Molecular Sciences 2013, 14, 3540-3555, https://doi.org/10.3390/ijms14023540.

28. Fessenden, R.J.; Fessenden, J. Organic Chemistry. Jakarta: Erlangga. 1992.

29. Helaly, S.E.; Thongbai, B.; Stadler, M. Diversity of biologically active secondary metabolites from endophytic and saprotrophic fungi of the ascomycete order xylariales. Natural. Product Report 2018, 35, 992-1014, https://doi.org/10.1039/c8np00010g.

30. Elkhateeb, W.A.; Daba, G.M.; Elnahas, M.O.; Thomas, P.W. The rarely isolated fungi: Arthrinium sacchari, Beltrania querna, and Papulaspora immersa, Potentials and Expectations. ARC Journal of Pharmaceutical Sciences (AJPS) 2019, 5, 1-6.

31. Rukachaisirikul, V.; Kaewbumrung, C.; Phongpaichit, S.; Hajiwangoh, Z. Eudesmane sesquiterpenes from the aquatic fungus Beltrania rhombica. Chem. Pharm. Bull 2005, 53, 238-240, https://doi.org/10.1248/cpb.53.238.

32. Ferreira, M.C.; Vieira, M.S.L.A.; Zani, C.L.; Alves, T.M.D.A.; Junior, P.A.S.; Murta, S.M.F.; Romanha, A.J.; Gil, L.H.V.G.; Carvalho, A.G.D.O.; Zilli, J.E.; Vital, M.J.S.; Rosa, C.A.; Rosa, L.H. Molecular phylogeny, diversity, symbiosis and discover of bioactive compounds of endophytic fungi associated with the medicinal Amazonian plant Carapa guianensis Aublet (Meliaceae). Biochemical Systematics and Ecology 2015, 59, 3644, https://doi.org/10.1016/j.bse.2014.12.017.

33. Fraga, B.M. Natural sesquiterpenoid. Natural product report 2003, 20, 392-413, https://doi.org/10.1039/B208084M.

34. Modzelewska, A.; Sur, S.; Kumar, S.K.; Khan, S.R. Sesquiterpenes: natural product that decrease cancer growth. Current Medical Chemistry-Anti-Cancer Agent 2005, 5, 477-499, https://doi.org/10.2174/1568011054866973.

35. Habisukan, U.H.; Elfita, W.H.; Setiawan, A. Chemical characterization of secondary metabolite from the endophytic fungus Trichordema reecei isolated from The Twig of Syzygium aqueum. Science and Technology Indonesia 2021, 6, 137-143, https://doi.org/10.26554/sti.2021.6.3.137-143.

36. Singh, A.; Singh, D.K.; Kharwar, R.N.; White, J.F.; Gond, S.K. Fungal Endophytes as Efficient Sources of Plant-Derived Bioactive Compounds and Their Prospective Applications in Natural Product Drug Discovery: Insights, Avenues, and Challenges. Microorganisms https://doi.org/10.3390/microorganisms9010197.

37. Tan, X.; Zhou, Y.; Zhou, X.; Xia, X.; Wei, Y.; He, L.; Tang, H.; Yu, L. Diversity and bioactive potential of culturable fungal endophytes of Dysosma versipellis; A rare medicinal plant endemic to China. Scientific Reports 2018, 8, 1-9, https://doi.org/10.1038/s41598-018-24313-2.

38. Adeleke, B. S.; Babalola, O. O. Pharmacological potential of fungal endophytes associated with medicinal plants: A review. Journal of Fungi 2021, 7, 1-16, https://doi.org/10.3390/jof7020147.

39. Zheng, R.; Li, S.; Zhang, X.; Zhao, C. Biological activites of some new secondary metabolites isolates from endophytic fungi: A review study. Int. J. Mol. Sci 2021, 22, https://doi.org/10.3390/ijms22020959. 